\title{
Modeling of temperature fields of details during laser hardening using the method of polyargument systems
}

\author{
V. G. Prokopov $\bullet$ N. M. Fialko $\bullet$ Ju. V. Sherenkovsky $\bullet$ V. L. Yurchuk • N. O. Meranova $\bullet$ \\ O. E. Maletskaya • A. B. Timoshchenko • M. V. Hanzha
}

Institute of Engineering Thermophysics of NAS of Ukraine Kyiv

Received: 01 November 2019 / Accepted: 22 November 2019

\begin{abstract}
The data of mathematical modeling of the thermal state of a cutting tool under conditions of laser hardening are presented. The features of the implementation of the method of polyargument systems for solving the three-dimensional heat transfer problem with a localized movable laser heating source are considered. The data of numerical studies to establish patterns of the influence of the radius of the heating spot on the temperature regime of the hardened tool are presented. It is shown that varying this parameter can be used as an effective way of influencing the thermal state of a cutting tool during its hardening by a laser beam. The results of modeling the temperature conditions of the tool in a wide practically important range of changes in its sharpening angle are presented.

Keywords: laser beam hardening; methods of polyargument systems; temperature conditions; computer modelling.
\end{abstract}

\section{Introduction}

One of the characteristic features of laser hardening technologies is that the leading role in them belongs to heat processes. These processes are the root cause of different physical-chemical phenomena associated with heat ones. Such phenomena, in particular, include structural and bulk transformations in materials, changes in the thermally stressed state of details, etc. So, an in-depth analysis of heat transfer processes in hardened details is relevant for these technologies.

In the analysis of the technologies under consideration, a special role belongs to mathematical modeling (see, for example, [1-3]). This is due, firstly, to the fact that in a number of cases conducting full-scale experiments is expensive and, moreover, it is extremely difficult by a combination of additional factors, such as high heating and cooling rates, the practical inaccessibility of individual sections of the studied objects of significant interest, localization of the zones of influence of concentrated energy flows, etc. In addition, the use of mathematical modeling in the study of the studied processes allows, as you know, to fill the gaps in the experimental work, as well as, very important, significantly reduce the volume of experiments.

This work is devoted to the study of heat transfer processes during laser hardening based on mathematical modeling.

\section{Study objectives}

The purpose of the article is to identify the effects of structural and operational parameters on the temperature conditions of the cutting tool during laser hardening

\section{Problem statement and research methodology}

The physical formulation of the heat transfer problem for the situation under consideration is formulated as follows. A normally distributed laser heating source $q(r, z)$ with a constant speed $\mathrm{V}$ moves along the surface of the cutting tool parallel to the $\mathrm{z}$ axis at a certain distance from it, Fig. 1. The following notation is used in the figure: $P e=V \cdot r_{0}^{\prime} / a_{0} ; q^{*}=\frac{q(r, z)}{q_{\max }} ; r=r_{p} / r_{0}^{\prime} ; z=z_{p} / r_{0}^{\prime} ; a^{*}=a_{p}^{*} / r_{0 p} ; q_{\max }-$ maximum value of the heat input diagram;

$\triangle$ N.M. Fialko nmfialko@ukr.net

\section{$\bowtie$ Ju.V. Sherenkovsky} j_sher@ukr.net
V.L. Yurchuk vyur1@ukr.net 


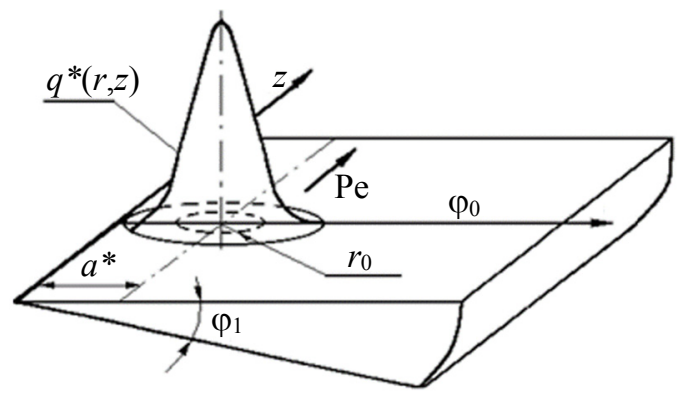

Fig. 1. To the statement of the problem

$r_{0 p}, \quad r_{0}^{\prime}$ - the variable and characteristic value of the radius of the heating spot; $r_{p}, z_{p}$-dimensionless coordinates; $a_{0}$ is a fixed value of the coefficient of thermal diffusivity of the tool material).

We consider the situation corresponding to the unchanged heat transfer conditions of the part with the environment, which is described by the Newton-Richmann law. The ambient temperature $t_{c}$ and the heat transfer coefficient are assumed to be constant and the same for all bounding surfaces.

The mathematical formulation of the problem under consideration is given in [2].

The problem was solved using the method of polyargument systems (MPS), focused on solving multidimensional transfer problems [4-6]. This class of methods can be interpreted as a logical generalization and development of projection methods - one of the most important approaches of modern computational mathematics.

The basis for constructing methods of polyargument systems are the following three points.

The first point can be formulated as a desire to eliminate the necessity to use any a priori elements in the desired solution and to determine to the maximum extent possible all the information required to construct the solution, based only on a given mathematical statement of the problem. The a priori elements to be eliminated in the basic methods noted above are primarily the basic functions, as well as some additional functions that ensure satisfaction of the boundary conditions, taking into account the shape of the region, etc.

The second point is the most important concept for constructing this class of methods - the concept of the completeness of functional reflection. The essence of this concept can be formulated as some requirement for the features of the reflection of the initial information in a reduced formulation. According to this requirement, it is necessary to be able to reflect the information appearing in the original mathematical model in a functional form, also in a functional form, i.e. in the form of functions of one or another argument. Moreover, the very specificity of the construction of methods should provide the possibility of implementing such a functional reflection both partially and (which is especially important) with the maximum possible completeness allowed by the accepted restrictions.

The third point characterizes the main limitation, in the framework of which two previous provisions are implemented. In this paper, such a limitation is to reduce the original multidimensional problem to special onedimensional ones, i.e. to problems formulated ultimately for systems of ordinary differential equations. Acceptance of this condition is motivated mainly by the following two considerations. Firstly, the need to have a well-developed mathematical apparatus that can be effectively applied to solve a reduced problem. And, secondly, the ability to reflect in the reduced statement the initial functional information in a functional form, as required by the above concept.

The above three points that underlie the construction of methods of polyargument systems, and above all the concept of completeness of functional reflection, provide high efficiency of the developed approach for solving different multidimensional transfer problems.

\section{Research results}

The temperature conditions of details during laser hardening to a large extent determine the final technological result. One of the ways to influence the temperature regime of a cutting tool is to change the value of the laser heating $\operatorname{spot} r_{0}$.

Typical results of numerical studies of the heat state of the cutting tool for different values of $r_{0}$. are shown in Fig. 2, 3. The data presented correspond to the following initial parameters: $\varphi_{1}=\pi / 3, a^{*}=1.0, B i=1.064 \cdot 10^{-3}$; cutting tool material - steel U8; $r_{0}=0.5 ; 0.75 ; 1.0 ; 1.5 ;\left(B i=\frac{\alpha \cdot r_{0}^{\prime}}{\lambda_{0}}, \quad r_{0}=\frac{r_{0 p}}{r_{0}^{\prime}}, \alpha\right.$ - heat transfer coefficient, $\lambda_{0}-$ fixed value of the thermal conductivity coefficient of the material of the cutting tool; as the characteristic size was taken $r_{0}^{\prime}=2 \cdot 10^{-3} \mathrm{~m}$.

For different calculation options corresponding to different $r_{0}$, the heat flux $q_{\max }$ were determined from the correlation $q_{\max }=Q_{l} /\left(\pi \cdot r_{0 p}^{2}\right)$, where $Q_{l}=Q_{l}^{*} \cdot A, Q_{l}^{*}$ is the laser radiation power, $A$ is the absorption capacity of the cutting tool material.

Characterizing in general the features of the influence of the parameter $r_{0}$ on the temperature regime of the tool, it should be noted that this influence for cutting tool and a semi-infinite array is significantly different. $S_{0}$, in a semiinfinite array, $r_{0}$ does not affect the qualitative nature of the temperature distribution. In the case of a cutting tool, the 


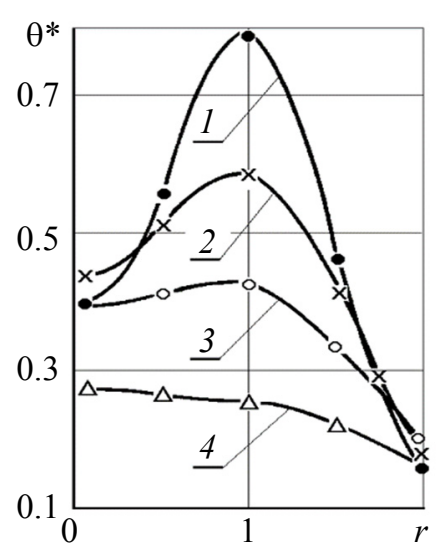

Fig. 2. The change in temperature $\theta^{*}$ of tool along the radius at $\varphi=0, z=-0.5, \varphi_{1}=\pi / 3$, $a^{*}=1.0, P e=4.5$ for different values of $r_{0}$ :

$1-r_{0}=0.5 ; 2-0.75 ; 3-1.0 ; 4-1.5$

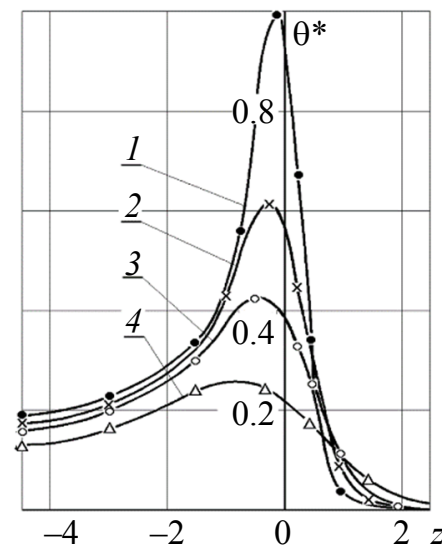

Fig. 3. The change in temperature $\theta^{*}$ of tool in the direction of the axis $z$ at $\varphi=0$, $r=1.0, \varphi_{1}=\pi / 3, a^{*}=1.0, P e=4.5$ for different values of $r_{0}: 1-r_{0}=0.5 ; 2-0.75$; $3-1.0 ; 4-1.5$

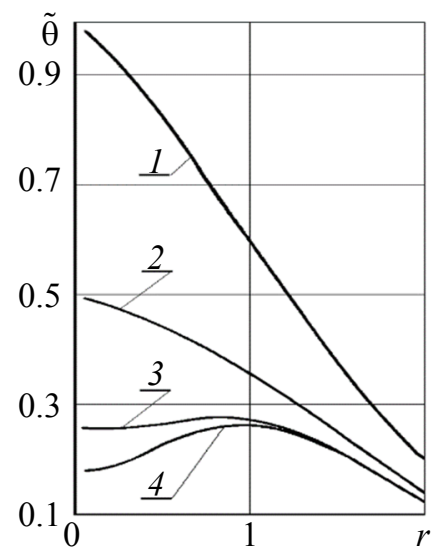

Fig. 4. The change in temperature $\tilde{\theta}$ along the radius at $\varphi=0, z=-0.5, a^{*}=1.0, r_{0}=1.0$, $P e=4.5$ for different values $\varphi_{1}: 1-\varphi_{1}=\pi / 12$; $2-\pi / 6 ; 3-\pi / 3 ; 4-\pi / 2$ opposite is true. Namely, here the temperature distributions corresponding to different values of $r_{0}$ can differ not only quantitatively, but also qualitatively. Indeed, as can be seen from Fig. 2, for relatively small values of $r_{0}$, the temperature distribution of the tool $\theta^{*}$ along the radius is extreme (see lines 1,2 and 3 on the graph). In the case of sufficiently large values of $r_{0}$ (line 4 on the graph), there is a monotonic drop in the temperature of the tool $\theta^{*}$ with distance from the cutting edge. (Here the value $\theta^{*}$ represents the ratio $\theta / / \theta_{\text {max }_{1}}$, where $\theta_{\text {max }_{1}}$ is the dimensionless maximum temperature of the tool at $r_{0}=0.5$ ).

As for the quantitative differences of the compared temperatures, so as follows from the data obtained (see Figs. 2 and 3), in the zone adjacent to the maximum heat supply, a significant deviation of temperatures corresponding to different $r_{0}$ is observed. Moreover, the temperature levels of the tool are higher, the smaller, ceteris paribus, the value of $r_{0}$. As the distance from the location of the maximum of the heat supply, the differences in temperatures related to different $r_{0}$ generally decrease markedly. (So, as can be seen from Fig. 2, at $r=1$, the deviation of the compared temperatures $\theta^{*}$ reaches 0.55 , and at some distance from it at $r=2$ it does not exceed 0.05). This is due to the effect of the localization influence of specifics on the localization of the spatial distribution of the heat flux supplied to the tool.

According to the data obtained, the inversion of the compared temperature curves is seen in front of the laser heating source in the direction of its movement (see Fig. 3). A similar picture takes place in the direction of the radial coordinate (Fig. 2).

It is also of interest to analyze the features of the influence on the heat state of the tool during hardening of the sharpening angle $\varphi_{1}$. The characteristic results of the performed computational experiments, which correspond to different values of $\varphi_{1}$, are presented in Fig. 4 and 5. (Here, $\tilde{\theta}=\theta / \theta_{\max }^{* *}$, where $\theta_{\max }^{* *}$ is the dimensionless maximum temperature of the tool at $\varphi_{1}=\pi / 12$ ). As you can see, with an increase in the angle $\varphi_{1}$, ceteris paribus, the temperature level of the tool as a whole decreases. It is important to emphasize that on the hardened surface, the greatest differences in temperature corresponding to different sharpening angles occur near the cutting edge. With the radial direction away from it, these differences decrease and turn out to be very insignificant at a sufficiently large distance (see Fig. 4). Thus, under the considered conditions, at some distance from the cutting edge, the effect of localization of the influence of the tool sharpening angle takes place.

As follows from the data obtained, the value of the sharpening angle $\varphi_{1}$ determines not only the temperature level in the detail, but can also have a significant effect on the nature of the temperature field of the tool as a whole. So, at small tool sharpening angles, extreme temperature values are observed directly on the sharp edge (lines 1 and 2 in Fig. 4). As the angle $\varphi_{1}$ increases, the extremum shifts in the radial direction (lines 3 and 4 on the graph).

It is also noteworthy that the effects of the angle $\varphi_{1}$ turn out to be different in different ranges of its change. As follows from the data obtained, at relatively small tool sharpening angles $\left(\varphi_{1}<\pi / 6\right)$, a change in $\varphi_{1}$ has a very significant effect on the temperature level in the high- 


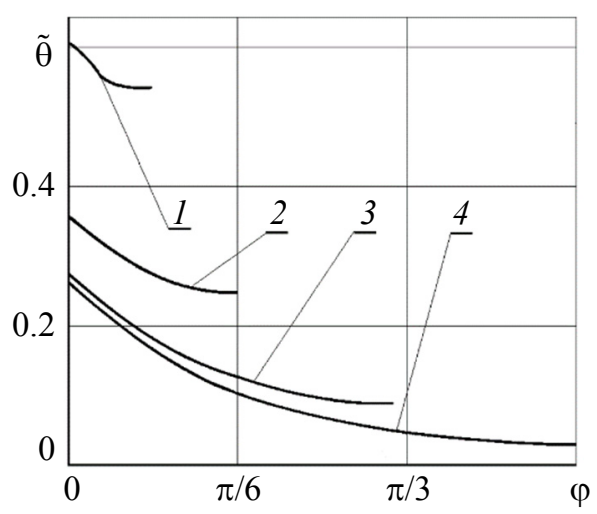

Fig. 5. Dependence $\tilde{\theta}=f(\varphi)$ for $r=1.0$, $z=-0.5, r_{0}=a^{*}=1.0, P e=4.5$ for various tool sharpening angles $\varphi_{1}: 1-\varphi_{1}=\pi / 12$;

$$
2-\pi / 6 ; 3-\pi / 3 ; 4-\pi / 2
$$

temperature zone (compare lines 1 and 2 in Figs. 4 and 5). In the case of sufficiently large angles $\varphi_{1}\left(\varphi_{1}>\pi / 3\right)$, the influence of 1 on the formation of the thermal state of the instrument is not so significant (compare lines 3 and 4 in the graphs). This circumstance, obviously, is associated with the phenomenon of localization of the influence of the unheated surface of the tool $\varphi=\varphi_{1}$, which is observed at relatively large sharpening angles. Indeed, in situations corresponding to large values of $\varphi_{1}$, the effect of the unheated surface of the tool $\varphi_{1}$ on the temperature distribution in the high-temperature zone is significantly weakened compared to that in the case of small angles $\varphi_{1}$. And accordingly, in this situation, the indicated temperature distribution will be determined primarily by the heat supply conditions themselves.

As for the features of the behavior of the temperature of the tool in the tangential direction for various values of its sharpening angle, the picture here as a whole is as follows. The decrease in the temperature of the tool in the tangential direction is the more significant, the larger the value of the angle $\varphi_{1}$. In this case, temperature deviations corresponding to different sharpening angles $\varphi_{1}$ vary slightly with increasing $\varphi$, and increasing slightly as they approach the unheated tool boundary surface $\varphi=\varphi_{1}$ (see Fig. 5).

\title{
Conclusions
}

Based on the method of polyargument systems, data on the laws of the influence of various factors on the heat state of a cutting tool hardened by a laser beam were obtained. Wherein:

1. The effects of the influence of the radius of the heating spot on the temperature regime of the instrument are established and their interpretation is given taking into account the localization phenomenon.

2. The analysis of the regularity of change in the heat state of the tool with varying the angle of its sharpening is performed.

\section{References}

1. Fialko N.M. Determination of threshold values of technological parameters of laser hardening on the basis of polyargument systems methods / N.M. Fialko, V.G. Prokopov, Ju.V. Sherenkovskiy, V.L. Yurchuk, N.O. Meranova, N.P. Polozenko // Scientific Bulletin of UNFU. - 2019. - Vol. 6. No. 29. - P. 92-97. doi: https://doi.org/10.15421/40290619

2. Prokopov V.G. Mathematical modeling of heat transfer processes at laser hardening based on methods of polyargument systems / V.G. Prokopov, N.M. Fialko, Ju.V. Sherenkovskiy, V.L. Yurchuk, N.O. Meranova, O.E. Maletska, N.P. Polozenko, O.N. Kutniak // Technological systems. - 2019. - Vol. 1. No. 85. - P. 24-28.

3. Shvets Yu.I., Fialko N.M., Golovko L.F. Otsenka teplovogo sostoianiia izdeliy pri uprochnenii materiala podvizhnym kontsentrirovannym istochnikom energii // Heat Industrial Engineering. - 1986. - No. 6. - P. 60-63.

4. Prokopov V.G. Primenenie metodov polyargumenrnykh system dlia resheniia nelinejnykh mnogomernykh zadach teploperenosa / V.G. Prokopov, E.I. Bespalova, Ju.V. Sherenkovskiy // University News. Energetics. - 1986, Vol. 33. P. 84-89.

5. Prokopov V.G. Pidvyschennia efektyvnosti modeluvannia bagatovymirnykh protsesiv teploperenosu na osnovi metodiv poliargumentnykh system ta teorii lokalizatsii. - Abstract dis. ... doctor of technical science. NTUU KPI. Kiev. - 2010. $44 \mathrm{p}$.

6. Fialko N. Determining the threshold permissible values of technological parameters at laser hardening based on the method of polyargument systems / N. Fialko, V. Prokopov, Ju. Sherenkovskiy, V. Yurchuk, O. Kutnyak // XLIII International sciences practical conference «Actual problems of modern science» (Kharkov - Vienna - Berlin - Astana), August 29. 2019. - P. 48-50.

\section{Моделирование температурных полей деталей при лазерной закалке с использованием метода полиаргументных систем}

\author{
В. Г. Прокопов, Н. М. Фиалко, Ю. В. Шеренковский, В. Л. Юрчук, Н. О. Меранова, О. Е. Малецкая,
} А. Б. Тимощенко, М. В. Ганжа

Аннотация. Представлены данные математического моделирования теплового состояния режущего инструмента в условиях лазерной закалки. Рассматриваются особенности реализации метода полиаргументных систем для решения 
трехмерной задачи теплопереноса с локализованным подвижным источником лазерного нагрева. Приводятся данные численных исследований по установлению закономерностей влияния радиуса пятна нагрева на температурный режим упрочняемого инструмента. Показано, что варьирование данного параметра может использоваться в качестве эффективного способа воздействия на тепловое состояние режущего инструмента в процессе его закалки лучом лазера. Представлены результаты моделирования температурных режимов инструмента в иироком практически важном диапазоне изменения его угла заточки.

Ключевые слова: упрочнение лучом лазера; методы полиаргументных систем; температурные режимы; компьютерное моделирование.

\title{
Моделювання температурних полів деталей при лазерному загартуванні 3 використанням методу поліаргументних систем
}

\author{
В. Г. Прокопов, Н. М. Фіалко, Ю. В. Шеренковський, В. Л. Юрчук, Н. О. Меранова, О. Є. Малецька, \\ О. Б. Тимощенко, М. В. Ганжа
}

Анотація. Представлено дані математичного моделювання теплового стану ріжучого інструменту в умовах лазерного загартування. Розглядаються особливості реалізачї методу поліаргументних систем для розв'язання тривимірної задачі теплопереносу з локалізованим рухомим джерелом лазерного нагріву. Наводяться дані числових досліджень щодо встановлення закономірностей впливу радіуса плями нагріву на температурний режим зміцнюваного інструменту. Показано, що варіювання даного параметра може використовуватися як ефективний спосіб впливу на тепловий стан ріжучого інструменту в процесі його загартування променем лазера. Представлено результати моделювання температурних режимів інструмента в широкому практично важливому діапазоні зміни його кута заточки.

Ключові слова: зміцнення променем лазера; методи поліаргументних систем; температурні режими; комп'ютерне моделювання.

\section{References}

1. Fialko, N.M., Prokopov, V.G., Sherenkovskiy, Ju.V., Yurchuk, V.L., Meranova, N.O. and Polozenko, N.P. (2019), "Determination of threshold values of technological parameters of laser hardening on the basis of polyargument systems methods" Scientific Bulletin of UNFU, vol. 6, no. 29, pp. 92-97. doi: https://doi.org/10.15421/40290619

2. Prokopov, V.G., Fialko, N.M., Sherenkovskiy Ju.V., Yurchuk, V.L., Meranova, N.O., Maletska, O.E., Polozenko, N.P. and Kutniak, O.N. (2019), "Mathematical modeling of heat transfer processes at laser hardening based on methods of polyargument systems", Technological systems, vol. 1, no. 85, pp. 24-28.

3. Shvets, Yu.I., Fialko, N.M. and Golovko, L.F. (1986), "Otsenka teplovogo sostoianiia izdeliy pri uprochnenii materiala podvizhnym kontsentrirovannym istochnikom energii”, Heat Industrial Engineering, no. 6, pp. 60-63.

4. Prokopov, V.G., Bespalova, E.I. and Sherenkovskiy, Ju.V. (1986), "Primenenie metodov polyargumenrnykh system dlia resheniia nelinejnykh mnogomernykh zadach teploperenosa", University News. Energetics, vol. 33, pp. 84-89.

5. Prokopov, V.G. (2010), "Pidvyschennia efektyvnosti modeluvannia bagatovymirnykh protsesiv teploperenosu na osnovi metodiv poliargumentnykh system ta teorii lokalizatsii", Abstract dis. ... doctor of technical science, NTUU "KPI", Kyiv, Ukraine.

6. Fialko, N., Prokopov, V., Sherenkovskiy, Ju., Yurchuk, V. Kutnyak, O. (2019), "Determining the threshold permissible values of technological parameters at laser hardening based on the method of polyargument systems", XLIII International sciences practical conference "Actual problems of modern science» (Kharkov- Vienna - Berlin - Astana), August 29, pp. $48-50$. 